\title{
Use of real-time quantitative reverse transcription polymerase chain reaction for the detection of African horse sickness virus replication in Culicoides imicola
}

\author{
Authors: \\ Elisabeth G. Scheffer ${ }^{1,4}$ \\ Gert J. Venter ${ }^{2,3}$ \\ Christopher Joone ${ }^{1}$ \\ Nikolaus Osterrieder ${ }^{4}$ \\ Alan J. Guthrie ${ }^{1}$

\section{Affiliations:} \\ ${ }^{1}$ Equine Research Centre, \\ University of Pretoria, \\ South Africa \\ ${ }^{2}$ Parasites, Vectors and \\ Vector-borne Diseases, \\ ARC-Onderstepoort \\ Veterinary Institute, \\ South Africa
}

${ }^{3}$ Department of Veterinary Tropical Diseases, University of Pretoria, South Africa

${ }^{4}$ Institut für Virologie, Freie Universität Berlin, Germany

Correspondence to:

Alan Guthrie

Email:

alan.guthrie@up.ac.za

Postal address:

Private bag X04,

Onderstepoort 0110,

South Africa

Dates:

Received: 21 May 2011 Accepted: 27 July 2011

Published: 11 Nov. 2011

How to cite this article: Scheffer, E.G., Venter, G.J., Joone, C., Osterrieder, N \& Guthrie, A.J., 2011, 'Use of real-time quantitative reverse transcription polymerase chain reaction for the detection of African horse sickness virus replication in Culicoides imicola', Onderstepoort Journal of Veterinary Research 78(1), Art. \#344, 4 pages. doi:10.4102/ojvr. v78i1.344

(C) 2011. The Authors. Licensee: AOSIS OpenJournals. This work is licensed under the Creative Commons Attribution License.
Despite its important role as vector for African horse sickness virus (AHSV), very little information is available on the dissemination of this virus in Culicoides (Avaritia) imicola Kieffer (Diptera: Ceratopogonidae). This study reports on the applicability of a real-time quantitative reverse transcription polymerase chain reaction (RT-qPCR) to detect AHSV in dissected midges. A total of 96 midges were fed on AHSV-infected blood, after which one test group was dissected into head/thorax and abdomen segments immediately after feeding and the other only after 10 days of incubation. The majority of the midges (96\%) ingested the virus successfully and there was no significant difference between the virus concentration in the heads/thoraxes and the abdomens immediately after feeding. After incubation, virus was detected in $51 \%$ of the midges and it was confined to the abdomen in the majority of these. The fact that virus was detected only in the heads/thoraxes of four Culicoides midges after incubation suggests the presence of a mesenteronal escape barrier. Replication in the salivary glands was not shown. An increase of the mean virus concentration in the abdomen after incubation indicates localised viral replication. The real-time RT-qPCR is recommended for further studies investigating the replication and dissemination of AHSV in Culicoides midges.

\section{Introduction}

Small biting midges in the genus Culicoides (Diptera: Ceratopogonidae) are involved in the epidemiology and transmission of a number of orbiviruses of veterinary importance, including African horse sickness virus (AHSV) with nine known serotypes (Howell 1962). This virus causes an infectious, non-contagious disease, African horse sickness (AHS), which is endemic in subSaharan Africa and can have a mortality rate of up to $95 \%$ in susceptible horses.

Based on its confirmed vector status, wide geographical distribution, abundance and host preference for larger mammals, the Afro-Asiatic Culicoides (Avaritia) imicola Kieffer is considered the principle vector of AHSV in South Africa (Meiswinkel, Venter \& Nevill 2004; Nevill, Venter \& Edwardes 1992). This species is also the most important vector of orbiviruses across vast geographic regions in Africa, the Mediterranean and southern Europe (Mellor, Boorman \& Baylis 2000). Following ingestion by a susceptible midge, AHSV infects and replicates in cells of the mesenteron before entering the haemocoel and infecting secondary target organs such as the fat body and salivary glands (Mellor 2000; Wittmann \& Baylis 2000). A number of barriers to arbovirus infection appear to exist in Culicoides midges, including the mesenteronal infection and escape barriers and the dissemination barrier. A salivary gland barrier has not been shown to be present in Culicoides species (Fu et al. 1999; Mellor 1990). Studies involving the North American vector Culicoides (Monoculicoides) sonorensis Wirth and Jones and bluetongue virus (BTV) indicate infection of the salivary glands to be an essential prerequisite for the transmission of virus (Jennings \& Mellor 1987). No comparable studies have been performed for C. imicola and/or AHSV.

A number of real-time reverse transcription polymerase chain reaction (RT-PCR) assays have been described for AHSV (Fernández-Pinero et al. 2009; Quan et al. 2010; Rodríguez-Sanchez et al. 2008), all with high sensitivity and a detection limit of $0.001-0.15 \mathrm{TCID}_{50}$ per reaction. A realtime quantitative RT-PCR (RT-qPCR) with a unique approach of using circulating field isolates of AHSV (Quan et al. 2010) has recently been used to determine the infection prevalence of AHSV in Culicoides midges. The use of PCR to investigate the replication and distribution of AHSV in Culicoides midges has not been described.

The objective of this study was to investigate the replication and dissemination of AHSV in fieldcollected C. imicola by feeding, incubating and dissecting individuals and performing real-time RT-qPCR on the abdomens and the heads/thoraxes. 


\section{Research method and design Materials and method}

Culicoides biting midges were collected alive using $220 \mathrm{~V}$ Onderstepoort downdraught suction light traps (Venter et al. 1998) at various sites near cattle at the ARC-Onderstepoort Veterinary Institute, South Africa (2539'S, 28 ${ }^{\circ} 11^{\prime} \mathrm{E} ; 1219 \mathrm{~m}$ above sea level). After an acclimatising period of 2-3 days at $23.5{ }^{\circ} \mathrm{C}$ and a relative humidity of $50 \%-70 \%$, field-collected midges were fed on defibrinated sheep blood containing AHSV serotype 6 at a concentration of $10^{6.1} \mathrm{TCID}_{50} / \mathrm{mL}$ through a chicken skin membrane (Venter et al. 1991). After a feeding period of 30-40 min the blood-engorged females were separated into two groups: one group was dissected within hours after blood feeding $\left(D_{0}\right)$, whilst the other group was dissected after 10 days' incubation $\left(D_{10}\right)$. The blood-engorged females were maintained on a $5 \%(\mathrm{w} / \mathrm{v})$ sucrose solution containing antibiotics (500 IU penicillin, $500 \mu \mathrm{g}$ streptomycin and $1.25 \mu \mathrm{g}$ fungizone per $1 \mathrm{~mL}$ sucrose solution) at $23.5^{\circ} \mathrm{C}$ (Venter \& Paweska 2007). Midges were identified as C. imicola by examination of wing pattern. Straight Vanna's microscissors (Agar Scientific, Essex, UK) were used to separate the abdomen (containing the midgut) from the head/thorax (containing the salivary glands). Midges that could not be dissected immediately after feeding or incubation were stored overnight in a refrigerator at $4{ }^{\circ} \mathrm{C}$ or in a freezer at $-70^{\circ} \mathrm{C}$ if stored for a longer period.

The dissected midges were subjected to real-time RT-qPCR following an adaption of the protocol described by Quan et al. (2010). Culicoides parts were placed separately in MagNA Lyser green beads (Roche Products, South Africa), containing $300 \mu \mathrm{L}$ lysis/binding solution (AM8500) from the Ambion total nucleic acid extraction kit (AM1836), to which $2.1 \mu \mathrm{L}$ $\beta$-mercaptoethanol was added, or in $300 \mu \mathrm{L}$ phosphatebuffered saline. After homogenisation in a MagNA Lyser (Roche Products, South Africa), $100 \mu \mathrm{L}$ of each sample was mixed with $1 \mu \mathrm{L}$ carrier RNA, $60 \mu \mathrm{L}$ isopropanol and $20 \mu \mathrm{L}$ bead mix, the latter consisting of lysis/binding enhancer and magnetic beads. RNA extraction was performed using either the MagMAX Express Magnetic Particle Processor (Life Technologies, USA) or the Kingfisher Flex Automated Purification System (ThermoFisher Scientific, Finland). Purified water and blood from a clinical case of AHS were used as negative and positive controls, respectively. An aliquot of $5 \mu \mathrm{L}$ of each extract was mixed with $5 \mu \mathrm{L}$ primers and probe for part of segment 8 , which codes for the structural protein VP7 (Quan et al. 2010), to obtain final concentrations of $400 \mathrm{nM}$ for each primer and $180 \mathrm{nM}$ for the probe in the $25 \mu \mathrm{L}$ reaction. The samples were centrifuged, denatured at $95{ }^{\circ} \mathrm{C}$ for $1 \mathrm{~min}$ using a PCR machine (GeneAmp 9700, Life Technologies, USA) and rapidly chilled at $-20{ }^{\circ} \mathrm{C}$ for $5 \mathrm{~min}$. A total volume of $15 \mu \mathrm{L}$ master mix $(12.5 \mu \mathrm{L} 2 \mathrm{x}$ RTPCR buffer, $1 \mu \mathrm{L}$ 25x RT-PCR enzyme and $1.5 \mu \mathrm{L}$ purified water) was added before the samples were centrifuged again. RT-qPCR was performed using the StepOne Plus Real Time PCR system (Life Technologies, USA) according to the manufacturer's instructions.

Analysis of variance (ANOVA) was used to differentiate between mean cycle threshold $\left(\mathrm{C}_{\mathrm{T}}\right)$ values. Statistical differences between experimental groups were analysed using Fisher's exact test and/or $\chi^{2}$ analysis. $P$-values $<0.05$ were considered statistically significant.

\section{Results}

The results of the RT-qPCR assays on the abdomens and heads/thoraxes of $47 \mathrm{D}_{0}$ and $49 \mathrm{D}_{10}$ C. imicola, respectively, are provided in Table 1. AHSV was detected in 45 (95.7\%) $\mathrm{D}_{0}$ midges, three of which $(6 \%)$ contained virus only in the head/thorax. There was a significant difference between the number of Culicoides that tested PCR positive for AHSV in the abdomen (89.4\%) and in the head/thorax (34\%). AHSV was detected in $25 \mathrm{D}_{10}$ midges (51\%), with a significantly higher number being PCR positive for AHSV in the abdomen $(49 \%)$ than in the head/thorax $(8.2 \%)$.

There was a significant $(p<0.001)$ decrease in the number of midges in which AHSV was detected in either the head/ thorax or the abdomen immediately after blood feeding $(95.7 \%)$ than after 10 days' incubation (51\%). Based on the $\mathrm{C}_{\mathrm{T}}$ values no significant difference was identified in the AHSV concentration between heads/thoraxes and abdomens of $\mathrm{D}_{0}$ C. imicola $(p>0.05)$. Only one of the four positive $\mathrm{D}_{10}$ heads / thoraxes $(25 \%)$ had a $C_{T}$ value below the $D_{0}$ mean, whereas 18 of the 24 positive abdomens $(75 \%)$ had $C_{T}$ values below the mean of $\mathrm{D}_{0}$.

\section{Discussion}

With use of RT-qPCR, AHSV RNA was detected in 95.7\% of the Culicoides midges assayed immediately after feeding on an AHSV-infected blood meal. In previous studies, where similar infection techniques were used, AHSV was isolated only in $44 \%$ - $64 \%$ of the midges tested immediately after feeding when using cell culture systems (Venter \& Paweska

TABLE 1: Summary of real-time RT-qPCR results for body segments of Culicoides imicola after feeding on AHSV-6 infected blood.

\begin{tabular}{|c|c|c|c|c|c|c|}
\hline \multirow[t]{3}{*}{ Category } & \multicolumn{6}{|c|}{ Test group $^{\mathrm{a}}$} \\
\hline & \multicolumn{3}{|c|}{$\mathrm{D}_{0}(n=47)$} & \multicolumn{3}{|c|}{$\mathrm{D}_{10}(n=49)$} \\
\hline & Head/thorax & Abdomen & $\begin{array}{c}\text { Head/thorax or } \\
\text { abdomen }\end{array}$ & Head/thorax & Abdomen & $\begin{array}{c}\text { Head/thorax or } \\
\text { abdomen }\end{array}$ \\
\hline Mean $C_{T}$ (range) & $\begin{array}{c}35.83 \\
(31.76-39.39)\end{array}$ & $\begin{array}{c}34.67 \\
(31.49-39.27)\end{array}$ & - & $\begin{array}{c}36.74 \\
(30.94-39.95)\end{array}$ & $\begin{array}{c}32.52 \\
(26.55-39.60)\end{array}$ & - \\
\hline Number of midges below mean $C_{T}$ of $D_{0}$ & 7 & 23 & - & 1 & 18 & - \\
\hline
\end{tabular}


2007; Venter, Graham \& Hamblin 2000). In the present study, AHSV RNA was detected in $51 \%$ of the midges assayed after incubation. Previous oral susceptibility studies using identical incubation conditions reported markedly lower virus recovery. Depending on the virus isolate used, results for C. imicola ranged from $4.3 \%$ to $26.8 \%$ (Paweska \& Venter 2003; Venter \& Paweska 2007; Venter et al. 2000). In these studies AHS virions were detected using virus isolation on cell culture systems. RT-qPCR, however, detects viral RNA. This technique has been shown to be substantially more sensitive than virus isolation (Quan et al. 2010), which may explain the higher values reported in the present study.

In most of the $\mathrm{D}_{0}$ midges in which AHSV was found in the head/thorax, virus was also detected in the abdomen. The three C. imicola that tested PCR positive only in the head/ thorax were probably harvested and immobilised whilst still taking up the blood meal. The AHSV loads detected in the heads/thoraxes and abdomens of $\mathrm{D}_{0} \mathrm{C}$. imicola were similar $(p>0.05)$, implying that no virus replication had taken place yet. However, the mean $C_{T}$ value for the abdomens was lower in $\mathrm{D}_{10}$ midges (32.52) than in $\mathrm{D}_{0}$ midges (34.67). A drop of 3.32 in $\mathrm{C}_{\mathrm{T}}$ values implies a 10-fold increase of doublestranded RNA (Quan et al. 2010); the observed decrease of 2.15 therefore reveals approximately five times more viral RNA in the abdomens of $D_{10}$ midges compared to $D_{0}$ midges. The results are even more prominent if one looks at the lowest $C_{T}$ value of the abdomens (31.49 in $D_{0}$ and 26.55 in $D_{10}$ midges, respectively). This difference of almost five $C_{T}$ values indicates more than a 50 -fold increase of virus load in the abdomens, which was probably due to virus replication in the midgut cells.

It has been shown that Culicoides midges express various barriers that limit virus replication and transmission. The present results clearly illustrate that not all midges in a population are susceptible to infection with AHSV and that some individuals are able to clear the virus to below detectable levels within 10 days after feeding on a virus-infected blood meal. The mesenteronal infection barrier may have played a role in the proportion of $D_{10}$ midges $(49 \%)$ that were able to eliminate AHSV within 10 days without becoming infected. Culicoides midges that were PCR positive in the abdomen but exhibited a $C_{T}$ value below detectable limits in the head/thorax probably expressed a mesenteronal escape barrier, not allowing the virus to escape from the midgut cells. This result relates to a previous study where $43.6 \%$ of C. sonorensis exhibited such a barrier to BTV (Jennings \& Mellor 1987). In the present study, only four $(8.2 \%)$ of the $D_{10}$ midges were PCR positive in the head/thorax, indicating that they expressed neither a mesenteronal escape barrier nor a dissemination barrier. Virus that is present in the head/thorax is presumably located in the salivary glands. All four these midges had a higher $C_{T}$ value in the head/ thorax than in the abdomen (i.e. less viral RNA in the head/ thorax), implying that no additional viral replication had taken place in the salivary glands. The salivary glands were not specifically dissected but remained part of the heads/ thoraxes. However, this study does not indicate whether this could have influenced the results and secondary viral replication in the salivary glands remains unlikely. The mean $C_{T}$ value of the heads/thoraxes of the $D_{10}$ midges was not significantly different from that of the $\mathrm{D}_{0}$ midges $(p=$ 0.3847). However, the value was 4.22 units higher than for the abdomens in the former test group, which indicates a substantially lower viral load in their heads/thoraxes. The finding also supports the hypothesis that viral replication did not occur in the salivary glands.

\section{Conclusion}

The real-time RT-qPCR used in the present study was an adapted version of the protocol optimised for detection of AHSV in blood and organ samples (Quan et al. 2010). This adapted assay has recently been used to quantify viral loads in Culicoides midge pools and now it has been shown to be a very sensitive method for investigating AHSV viral load differences in different body parts of Culicoides midges as well. Future studies investigating AHSV replication in Culicoides midges should include investigations of AHSV viral load in salivary glands and/or saliva.

\section{Acknowledgments}

We thank the Veterinary Genetics Laboratory and the Department of Tropical Diseases of the University of Pretoria for providing the laboratory facilities. This research was supported by the Equine Research Centre of the University of Pretoria and the Freie Universität, Berlin provided a stipend for the principal investigator by means of the NaFoeG stipend.

\section{Authors' contributions}

A.J.G. and N.O. were the project leaders, whilst E.G.S., G.J.V. and A.J.G. were responsible for the experimental and project design. The experiments were performed by E.G.S. and C.J. and statistics were performed by G.J.V., E.G.S. wrote the manuscript with contributions from all authors.

\section{References}

Fernández-Pinero, J., Fernández-Pacheco, P., Rodríguez, B., Sotelo, E., Robles, A Arias, M. et al., 2009, 'Rapid and sensitive detection of African horse sickness virus by real-time PCR', Research in Veterinary Science 86, 353-358. doi:10.1016/j. rvsc.2008.07.015, PMid:18782637

Fu, H., Leake, C.J., Mertens, P.P. \& Mellor, P.S., 1999, 'The barriers to bluetongue virus infection, dissemination and transmission in the vector, Culicoides variipennis infection, dissemination and transmission in the vector, Culicoides variipennis
(Diptera: Ceratopogonidae)', Archives of Virology 144, 747-761. doi:10.1007/ (Diptera: Ceratopogonidae)', Archive
s007050050540, PMid:10365165

Howell, P.G., 1962, 'The isolation and identification of further antigenic types of African horsesickness virus', Onderstepoort Journal of Veterinary Research 29 139-149.

Jennings, D.M. \& Mellor, P.S., 1987, 'Variation in the responses of Culicoides variipennis (Diptera, Ceratopogonidae) to oral infection with bluetongue virus', Archives of Virology 95, 177-182. doi:10.1007/BF01310778, PMid:3038052

Meiswinkel, R., Venter, G.J. \& Nevill, E.M., 2004, 'Vectors: Culicoides spp.', in J.A.W. Coetzer \& R.C. Tustin (eds.), Infectious Diseases of Livestock, 2nd edn., pp. 93-136, Oxford University Press, Oxford.

Mellor, P.S., 1990, 'The replication of bluetongue virus in Culicoides vectors', Current Topics in Microbiology \& Immunology 162, 143-161.

Mellor, P.S., 2000, 'Replication of arboviruses in insect vectors', Journal of Comparative Pathology 123, 231-247. doi:10.1053/jcpa.2000.0434, PMid:11041993

Mellor, P.S., Boorman, J. \& Baylis, M., 2000, 'Culicoides biting midges: their role as arbovirus vectors', Annual Review of Entomology 45, 307-340. doi:10.1146/ annurev.ento.45.1.307, PMid:10761580 
Nevill, E.M., Venter, G.J. \& Edwardes, M., 1992, 'Potential Culicoides vectors of livestock orbiviruses in South Africa', in T.E. Walton \& B.I. Osburn (eds.), Bluetongue, African horse sickness, and related orbiviruses: Proceedings of the Second International Symposium, pp. 306-313, CRC Press, Boca Raton, Florida.

Paweska, J.T. \& Venter, G.J., 2003, 'Oral susceptibility of South African Culicoides species to live-attenuated serotype-specific vaccine strains of African horse sickness virus (AHSV)', Medical and Veterinary Entomology 17, 436-447. doi:10.1111/j.13652915.2003.00467.x, PMid:14651659

Quan, M., Lourens, C.W., Maclachlan, N.J., Gardner, I.A. \& Guthrie, A.J., 2010 'Development and optimisation of a duplex real-time reverse transcription quantitative PCR assay targeting the VP7 and NS2 genes of African horse sickness virus', Journal of Virological Methods 167, 45-52. doi:10.1016/j. jviromet.2010.03.009, PMid:20304015

Rodríguez-Sanchez, B., Fernández-Pinero, J., Sailleau, C., Zientara, S., Belak, S., Arias, M. et al., 2008, 'Novel gel-based and real-time PCR assays for the improved detection of African horse sickness virus', Journal of Virological Methods 151, 87-94. doi:10.1016/j.jviromet.2008.03.029, PMid:18501973
Venter, G.J., Graham, S.D. \& Hamblin, C., 2000, ‘African horse sickness epidemiology: Vector competence of South African Culicoides species for virus serotypes 3, and $8^{\prime}$, Medical and Veterinary Entomology 14, 245-250. doi:10.1046/j.13652915.2000.00245.x, PMid:11016430

Venter, G.J., Hill, E., Pajor, I.T.P. \& Nevill, E.M., 1991, 'The use of a membrane feeding technique to determine the infection rate of Culicoides imicola (Diptera: Ceratopogonidae) for 2 bluetongue virus serotypes in South Africa', Onderstepoort Journal of Veterinary Research 58, 5-9. PMid:1646980

Venter, G.J. \& Paweska, J.T., 2007, 'Virus recovery rates for wild-type and liveattenuated vaccine strains of African horse sickness virus serotype 7 in orally infected South African Culicoides species', Medical and Veterinary Entomology 21 377-383. doi:10.1111/j.1365-2915.2007.00706.x, PMid:18092976

Venter, G.J., Paweska, J.T., Van Dijk, A.A., Mellor, P.S. \& Tabachnick, W.J., 1998, 'Vector competence of Culicoides bolitinos and $C$. imicola for South African bluetongue virus serotypes 1, 3 and 4', Medical and Veterinary Entomology 12, 378-385. doi:10.1046/j.1365-2915.1998.00116.x, PMid:9824821

Wittmann, E.J. \& Baylis, M., 2000, 'Climate change: Effects on Culicoides-transmitted viruses and implications for the UK', Veterinary Journal 160, 107-117. doi:10.1053/ tvjl.2000.0470, PMid:10985802 